Journal of Epidemiology and Public Health (2019), 4(4): 314-319

https://doi.org/10.26911/jepublichealth.2019.04.04.06

\title{
Determinants of Compliance in Conducting Physiotherapy Among Patients with Low Back Pain in Medan Hospital, North Sumatera
}

\author{
Anita Andriany, Erna Mutiara, Halinda Sari Lubis \\ Masters Program in Public Health, Universitas Sumatera Utara
}

\begin{abstract}
Background: Lower back pain (LBP) is a symptom of pain that occurs in the lower back area. It is often experienced to those who have activities with the wrong posture. Based on visit data, the high proportion of non-compliance in conducting physiotherapy among LBP patients in Medan Regional Hospital in 2016 was $71.7 \%$. This study aimed to examine determinants of compliance in conducting physiotherapy among patients with LBP in Medan Hospital, North Sumatera.

Subjects and Method: This was a cross sectional study conducted at Medan Hospital, Sumatera Utara. A sample of 125 LBP patients was selected for this study by simple random sampling. The dependent variable was compliance to LBP physiotherapy. The independent variables were employment status, marital status, and family support. The data were obtained from medical record and questionnaire. The data were analyzed by a multiple logistic regression.

Results: Compliance to LBP physiotherapy increased with married (OR=1.31; 95\% CI 0.78 to 2.23; $\mathrm{p}=0.310)$, occupation $(\mathrm{OR}=1.83 ; 95 \% \mathrm{CI}=1.12$ to $3.02 ; \mathrm{p}=0.017)$, and family support $(\mathrm{OR}=$ $0.83 ; 95 \% \mathrm{CI}=0.36$ to $1.89 ; \mathrm{p}=0.652)$.

Conclusion: Compliance to LBP physiotherapy increases with married, occupation, and family support.
\end{abstract}

Keywords: ccompliance, pphysiotherapy, low back pain, patients

\section{Correspondence:}

Anita Andriany. Masters Program in Public Health, Universitas Sumatera Utara, Jl. Universitas 21, Medan 20155, North Sumatera, Indonesia. Email: dr.anita.andriany@gmail.com. Mobile: +6281262023731.

\section{BACKGROUND}

Lower back pain is a pain syndrome that occurs in the lower back area due to various causes. The prevalence of LBP in the United States in 1 year was $15-20 \%$. Besides, based on new patient visits to the doctor, the incidence of LBP was 14.3\% (Panduwinata, 2014). Sandhyadkk (2015) states that the prevalence of LBP in India was $74.2 \%$. Himnikaiye and Bamishaiye (2012) state that the prevelence of LBP in Nigeria was $78.1 \%$.

There is no epidemiological data of LBP in Indonesia. However, it is estimated that the prevalence of acute LBP was $40 \%$; $18.2 \%$ in male and $13.6 \%$ in female.
The total number of physiotherapy visits of LBP patients at Medical Rehabilitation Installation, Medan Regional Hospital, from January to April was 2,438 visits (43.9\%). The total number of patients who conducted physiotherapy at Medical Rehabilitation Installation, Medan Regional Hospital in 2016 was 273 people (42.0\%). The number of patients who conducted physiotherapy 6 times in August 2016 was 43 people (28.3\%). Besides, the number of patients who conducted physiotherapy less than 6 times was 109 people (71.7\%). 


\section{SUBJECTS AND METHOD \\ 1. Study Design \\ This study was a cross sectional study con- ducted at Medical Rehabilitation Installa- tion, Medan Hospital, Medan, North Suma- tera.}

\section{Study Sample}

A sample of 125 LBP patients was selected for this study by simple random sampling.

\section{Study Variables}

The dependent variable was compliance to LBP physiotherapy. The independent variables were occupation, marital status, and family support.

Table 1. Sample characteristics

\begin{tabular}{lcc}
\multicolumn{1}{c}{ Variable } & N & \% \\
\hline $\begin{array}{l}\text { Nompliance } \\
\text { Compliant }\end{array}$ & 90 & 72.0 \\
Sex & 35 & 28.0 \\
Male & & \\
Female & 51 & 40.8 \\
Occupation & 74 & 59.2 \\
Employee & & \\
Unemployed & 57 & 45.6 \\
Marital status & 68 & 54.4 \\
Unmarried & & \\
Married & 58 & 46.4 \\
Family Support & 67 & 53.6 \\
Weak & & \\
Strong & 94 & 75.2 \\
\hline
\end{tabular}

\section{Bivariate Analysis}

Table 2 showed the results of bivariate analysis. Table 2 showed that employed (OR= $1.83 ; 95 \% \mathrm{CI}=0.98$ to $3.40 ; \mathrm{p}=0.047$ ), married $(\mathrm{OR}=2.50 ; 95 \% \mathrm{CI}=1.28$ to 4.89 ; $\mathrm{p}=0.004)$, and strong family support $(\mathrm{OR}=$ $1.79 ; 95 \% \mathrm{CI}=1.03$ to $3.11 ; \mathrm{p}=0.046)$ increased patient compliance to conduct physiotherapy.

\section{Multivariate Analysis}

Table 3 shows the result of a multiple logistic regression. Table 3 showed that employ-

\section{Study Instrument}

The data were obtained from medical record and questionnaire.

\section{Data Analysis}

The data were analyzed by a multiple logistic regression.

\section{RESULTS}

\section{Univariate Analysis}

Table 1 showed that $72.0 \%$ of samples had irregular visit to physiotherapy. 59.2\% were female patients. $54.4 \%$ unemployed. $53.6 \%$ patients were married. $75.2 \%$ had weak family support. ment $(\mathrm{OR}=1.83 ; 95 \% \mathrm{CI}=1.12$ to $3.02 ; \mathrm{p}=$ o.017) increased patients compliance to conduct physiotherapy and it was statistically significant. Compliance to conduct physiotherapy increased with married $(\mathrm{OR}=1.31 ; 95 \% \mathrm{CI}=0.78$ to $2.23 ; \mathrm{p}=$ 0.310 ), but it was statistically non-significant. Compliance to conduct physiotherapy decreased with weak family support $(\mathrm{OR}=$ $0.83 ; 95 \% \mathrm{CI}=0.36$ to $1.89 ; \mathrm{p}=0.652)$, but it was statistically non-significant. 
Journal of Epidemiology and Public Health (2019), 4(4): 314-319

https://doi.org/10.26911/jepublichealth.2019.04.04.06

Table 2. The result of the bivariate analysis

\begin{tabular}{|c|c|c|c|c|c|c|c|c|}
\hline \multirow{3}{*}{ Variable } & \multicolumn{4}{|c|}{ Compliance } & & & \multirow{3}{*}{$\begin{array}{c}\text { OR } \\
95 \% \mathrm{CI}\end{array}$} & \multirow{3}{*}{$\mathbf{p}$} \\
\hline & \multicolumn{2}{|c|}{$\begin{array}{c}\text { Non- } \\
\text { compliant }\end{array}$} & \multicolumn{2}{|c|}{ Compliant } & \multicolumn{2}{|c|}{ Total } & & \\
\hline & $\mathbf{n}$ & $\%$ & $\mathbf{n}$ & $\%$ & $\mathbf{n}$ & $\%$ & & \\
\hline \multicolumn{9}{|l|}{ Sex } \\
\hline Male & 34 & 66.7 & 17 & $33 \cdot 3$ & 51 & 100.0 & \multirow{3}{*}{$\begin{array}{c}0.73 \\
(0.42-1.28)\end{array}$} & \multirow[t]{3}{*}{0.270} \\
\hline Female & 56 & $75 \cdot 7$ & 18 & $24 \cdot 3$ & 74 & 100.0 & & \\
\hline \multicolumn{7}{|l|}{ Occupation } & & \\
\hline Employee & 46 & 80.7 & 11 & 19.3 & 57 & 100.0 & 1.83 & \multirow[t]{3}{*}{0.047} \\
\hline \multirow{2}{*}{\multicolumn{8}{|c|}{ Marital Status }} & \\
\hline & & & & & & & & \\
\hline Unmarried & 49 & 84.5 & 9 & 15.5 & 58 & 100.0 & \multirow{3}{*}{$\begin{array}{c}2.50 \\
(1.28-4.89)\end{array}$} & \multirow{3}{*}{0.004} \\
\hline Married & 41 & 61.2 & 26 & 38.8 & 67 & 100.0 & & \\
\hline \multicolumn{7}{|l|}{ Family Support } & & \\
\hline Weak & 72 & 76.6 & 22 & 23.4 & 94 & 100.0 & 1.792 & \multirow{2}{*}{0.046} \\
\hline Strong & 18 & 58.1 & 13 & 41.9 & 31 & 100.0 & $(1.03-3.11)$ & \\
\hline
\end{tabular}

Table 3. The Result of Multiple Logistics Regression Analysis

\begin{tabular}{lcccc}
\hline \multirow{2}{*}{ Independent Variable } & \multirow{2}{*}{ OR } & \multicolumn{2}{c}{ 95\% CI } & \multirow{2}{*}{ p } \\
\cline { 3 - 4 } & & Lower limit & Upper limit & 0.652 \\
Weak Family Support & 0.83 & 0.36 & 1.89 & 0.310 \\
Married & 1.31 & 0.78 & 2.23 & 0.017 \\
Employed & 1.83 & 1.12 & 3.02 & 0 \\
\hline
\end{tabular}

\section{DISCUSSION}

1. The Association between Sex and Compliance with Physiotherapy

The results of data processing regarding the association between sex and compliance with physiotherapy in LBP patients in Medan General Hospital in 2016 showed that of 64 LBP patients who were male there were 40 patients $(62.5 \%)$ who were not compliant to do physiotherapists. There were 61 LBP patients who were female and 35 patients $(57.4 \%)$ were not compliant to do physiotherapy. Chi-Square statistical test results obtained the insignificant value of $\mathrm{p}>0.050$ which means there was no association between sex and compliance with physiotherapy in LBP patients in Medan General Hospital in 2016.

Falavigna et al. (2011) stated that there is a weak association between the sex of the patients and compliance with physiotherapy. The majority of male patients who comply with physiotherapy were 10 people
(45.50\%) and those who were not compliant did physiotherapy as many as 4 people (18.2\%). While female patients who comply with rehabilitation were 5 people (22.7\%) and those who were not compliant were 3 people (13.6\%). According to Onabajo et al. (2016) stated that men and women have the same risk of LBP complaints until the age of 60 years. However, sex can affect the onset of complaints of low back pain (Alexandre et al., 2002; Rutten et al., 2010).

\section{The Association between Occupa- tion and Compliance with Physio- therapy}

From the results of data processing regarding the association between occupation and compliance with physiotherapy in LBP patients in Medan General Hospital in 2016, it is obtained that from 94 LBP patients who worked, there were 60 patients (63.8\%) who were not compliant to do physiotherapy. Of the $31 \mathrm{LBP}$ patients who did not 
work, there were 15 LBP patients (48.4\%) who did not comply with physiotherapy.

Paraseth et al. (2018), who stated that there is an association between occupation and compliance with physiotherapy. This means that occupation does not significantly affect patient compliance in doing physiotherapy. Based on this study, it was found that LBP patients who were not compliant to do physiotherapy were 60 patients (63.8\%) patients who were worked. Occupation is referred to as one of the indirect risk factors that can cause LBP due to the risky physical activity undertaken.

Therefore, occupation is an indicator that can determine a person's socioeconomic status so the type of occupation can affect one's economic level. Someone who works will have a better economic or income level than those who do not work. Socioeconomic level is one of the factors that can affect compliance with physiotherapy for LBP patients (Paraseth et al., 2018).

\section{The Association between Marital Status and Compliance with Phy- siotherapy}

From the results of data processing regarding the association of marital status with compliance with physiotherapy in LBP patients, it was obtained that from 80 LBP patients who were married there were 54 patients (67.5\%) who did not comply with physiotherapy. Of the 45 LBP unmarried patients, there were 21 LBP patients (46.7\%) who did not comply with physiotherapy.

Al-Eisa (2010) stated that there was a weak association between marital status and compliance with undergoing rehabilitation. This can be interpreted that there is no association between the marital status of patients with compliance with undergoing rehabilitation.

Alexandre et al. (2002) stated that marital status is related to one's obedience.
Patients who are married have a greater level of compliance than patients who are not married. Someone who has a spouse (husband or wife) can help and remind about taking medication or therapy.

\section{The Association between Family Support and Compliance with Physiotherapy}

Based on the study, it was found that family support is one of the determinants associated with compliance with physiotherapy for LBP patients. The results showed that of 79 LBP patients who received family support there were 56 patients $(70.9 \%)$ who were not obediently do physiotherapy. Of the 46 LBP patients who lacked family support, there were 19 patients (41.3\%) who did not comply with physiotherapy. Jack et al. (2010) stated that there is an association between family support and compliance with visits to health facilities.

Bachmann et al. (2018) stated that success in completing and complying with the treatment is not only patient's responsibility but also must be seen from other factors. Factors associated to medication compliance are individual patient factors, social support, health support, and family support.

Support from the family is a factor that can affect patient compliance with regular treatment. The presence and attitude of the people closest to the patient can affect the response to pain. Sufferers who experience pain often depend on family member or peer support, assistance, or protection. Although the pain is still can be felt, the presence of those closest to you can minimize feelings of loneliness and fear. Family support is very important in helping patients recover. Family support also has an association with LBP patient compliance with treatment (Chaira, 2016; Palazzo et al., 2016). 
Journal of Epidemiology and Public Health (2019), 4(4): 314-319

https://doi.org/10.26911/jepublichealth.2019.04.04.06

\section{AUTHOR CONTRIBUTION}

Anita Andriany collected the data and wrote the manuscript. Erna Mutiara did data analysis. Halinda Sari Lubis suggested the discussion.

\section{FUNDING AND SPONSORSHIP}

There was no external funding.

\section{ACKNOWLEDGMENT}

We would like to thank the Medan Hospital, North Sumatera for giving permission to collect the data.

\section{CONFLICT OF INTEREST}

There was no conflict of interest in this study.

\section{REFERENCE}

Al-Eisa E (2010). Indicators of adherence to physiotherapy attendance among Saudi female patients with mechanical low back pain: A clinical audit.

Alexandre NMC, Nordin M, Hiebert R, Campello M (2002). Predictors of compliance with short-term treatment among patients with back pain. Rev Panam Salud Publica/Pan Am J Public Health. 12(2): 86-95.

Bachmann C, Oesch P, Bachmann S (2018). Recommendations for improving adherence to home-based exercise: A systematic review. Phys Med Rehab Kuror. 28(01): 20-31. Doi: 10.1055/s0043-120527.

Chaira S (2016). Pengaruh pengetahuan dan dukungan keluarga terhadap kepatuhan menjalani neurorehabilitasi pada pasien pasca stroke di unit rehabilitasi medik rsudza banda aceh. Jurnal Kesehatan Online. 1(4): 12-17. Retrieved December 28, 2017. from http://www.jim.unsyiah. ac.id/FKM/article/download/1509/803
Falavigna A, Teles AR, Mazzocchin T, de Braga GL, Kleber FD, Barreto F, Santin JT, Barazzetti D, et al. (2011). Increased prevalence of low back pain among physiotherapy students compared to medical students. Eur Spine J. 20: 500-505. Doi 10.1007/s00586010-1646-9.

Hinmikaiye C, Bamishaiye E (2012). The incidence of low back pain among theatre nurses: A case study of University of Ilorin and Obafemi Awolowo University Teaching Hospital. 2(3): 23-28. Retrieved from http://sapub.-org/pdf/10.5923.j.nursing.20120203.02.pdf

Jack K, McLean SM, Moffett JK, Gardiner E (2010). Barriers to treatment adherence in physiotherapy outpatient clinics: A systematic review. 15(3): 220228. https://doi.org/10.1016/j.math.2009.12.004.

Onabajo GOV, Nweze E, Gujba FK, Masta MA, Ali MU, Modu AA, Umeonwuka $C$ (2016). Prevalence of low back pain among undergraduate physiotherapy students in Nigeria. Pain Research and Treatment. http://dx.doi.org/10.1155/2016/1230384

Palazzo C, Klinger E, Dorner V, Kadri A, Thierry O, Boumenir Y, Martin W, et al. (2016). Barriers to home-based exercise program adherence with chronic low back pain: Patient expectations regarding new technologies. Annals of Physical and Rehabilitation Medicine. 59(2): 107-113. Doi: 10.1016/j.rehab.2016.01.009

Paraseth TK, Gajendran M, James D (2018). Approach to chronic low back pain in a Rural Mission Hospital: An audit report. CHRISMED J Health Res. 5: 43-7. Retrieved from http://www.cjhr.org/text.asp?2018/5/1/43/ 223118. 
Rutten GM, Degen S, Hendriks EJ, Braspenning JC, Harting $\mathrm{J}$, Oostendorp RA (2010). Adherence to clinical practice guidelines for low back pain in physical therapy: Do patients benefit? Physical Therapy. 90(8): 1111-1122. https://doi.org/10.2522/ptj.20090173 .
Sandhya R, Kumari M, Gopisankar, Sheela (2015). Prevalence of low back pain and knowlodge on body mechanics among the staff nursess in a tertiary care hospital. Journal Internasional Online. 3(9): 928-934. 